\title{
Mendorong Kedisiplinan Pegawai Melalui Budaya Organisasi, Kompetensi dan Kepuasan Kerja
}

\section{(Encouraging Employee Discipline through Organizational Culture, Competence and Job Satisfaction)}

Oleh:

\author{
Siti Khadijah Koto'), Anna Wulandari²) \\ Sekolah Tinggi Transportasi Darat Bekasi ${ }^{11}$, Universitas Pelita Bangsa2) \\ sitikhadijahkoto@gmail.com ${ }^{1)}$, drannawulandari@gmail.com²)
}

\begin{abstract}
ABSTRAK
Disiplin kerja menjadi permasalahan yang senantiasa terjadi di setiap organisasi termasuk lembaga pendidikan tinggi. Untuk membangunnya diperlukan upaya menelaah faktor penyebabnya. Oleh karena itu, tujuan penelitian ini adalah untuk mengetahui pengaruh budaya organisasi, kompetensi dan kepuasan kerja terhadap disiplin kerja pegawai. Penelitian dilakukan dengan menyebarkan kuesioner kepada 96 pegawai lembaga pendidikan tinggi di bekasi. Data hasil kuesioner dianalisis menggunakan analisis regresi linier ganda. Penelitian menghasilkan temuan bahwa Kompetensi dan kepuasan kerja merupakan faktor yang dapat mendorong kedisiplinan, sementara budaya organisasi bukan salah satu faktor yang dapat mendorong kedisiplinan. Kedisiplinan dapat diciptakan melalui peningkatan kompetensi dan kepuasan kerja.
\end{abstract}

Kata kunci:

Disiplin, Kompetensi, Kepuasan, Budaya Organisasi

\section{ABSTRACT}

Work discipline is a problem that always occurs in every organization, including higher education institutions. This requires an effort to examine the factors causing the problem. Therefore, the purpose of this study was to determine the influence of organizational culture, competence and job satisfaction on employee discipline. The study was conducted by submitting questionnaires to 96 employees of higher education institutions in Bekasi. The questionnaire results were analyzed using multiple linear regression analysis. The research resulted in the finding that competence and job satisfaction are factors that can encourage discipline, while organizational culture is not one of the factors that can encourage discipline. Discipline can be created through increasing competence and job satisfaction.

Keywords:

Organizational Culture, Competence, Job satisfaction, Employee Discipline 


\section{PENDAHULUAN}

Pegawai dalam bekerja mendasarkan diri pada nilai dasar, kode etik dan kode prilaku, komitmen, integritas moral, dan tanggung jawab pada publik, kompetensi yang diperlukan sesuai dengan bidang tugas, kualifikasi akademik, jaminan perlindungan hukum dan melakukan tugas dan profesionalitas jabatan. Pegawai memerlukan pembimbingan agar memiliki sikap dan prilaku yang berintikan pengabdian, kejujuran, tanggung jawab, disiplin serta berwibawa sehingga dapat memberikan pelayanan sesuai tuntutan perkembangan masyarakat. Untuk itu diperlukan kedisiplinan dalam menjalankan kewajiban sebagai anggota organisasi.

Kedisiplinan sangat penting untuk pertumbuhan organisasi, digunakan terutama untuk memotivasi pegawai agar dapat mendisiplinkan diri dalam melaksanakan pekerjaan baik secara perorangan maupun kelompok. Disamping itu disiplin bermanfaat mendidik pegawai untuk mematuhi dan menyenangi peraturan, prosedur, maupun kebijakan yang ada, sehingga dapat menghasilkan kinerja yang baik.

Begitu pentingnya disiplin kerja pegawai, mendorong dilakukannya penelitian mengenai kedisiplinan. Penelitian dilakukan diberbagai organisasi seperti lembaga pemerintah (Astraina, 2018), lembaga pendidikan (Widyaningsih, 2016; Rahayu, 2014), Perusahaan manufaktur (Tiara dan Prakoso, 2018), Media (Jaya, 2015), Pariwisata (Sudarwin, 2014), Perbankan (Hadi, 2012), dan Perusahaan Persero (Oktaviani dan Saragih, 2017; Damayanti dan Fakhri (2014; Pribadi dan Herlena, 2016; Hadi, 2012; Ilahi, Mukzan dan Prasetya, 2017).
Pada prakteknya di lembaga pendidikan tinggi masih banyak terjadi ketidakdisiplinan pegawai. Selama bulan Maret tahun 2019 sebagaimana observasi yang telah dilakukan, terdapat 63,36\% pegawai yang melakukan pelanggaran dalam berbagai kategori seperti datang terlambat dan pulang cepat dan pelanggaran tata tertib lainnya. Hal tersebut menunjukan tingkat disiplin pegawai yang masih rendah.

Perlu dikenali berbagai macam faktor yang dapat mendorong peningkatan disiplin kerja pegawai. Kepuasan (Sudarwin, 2014; Tiara dan Prakoso, 2018; Hadi, 2012), Kompetensi (Widyaningsih, 2016; Astraina, 2018, Rahayu, 2014), Budaya (Astraina, 2018; Jaya, 2015; Pribadi dan Herlena, 2016; Oktaviani dan Saragih, 2017; Damayanti dan Fakhri, 2014) merupakan faktor yang paling banyak diteliti.

Penelitian menghasilkan temuan yang beragam ada yang sama ada yang berbeda. Perbedaan terjadi karena obyek yang berbeda dan variabel yang disandingkan dalam penelitian juga berbeda. Meskipun sebagia besar kepuasan mempengaruhi kedisiplinan, tetapi ada juga temuan sebaliknya (Hadi, 2012). Demikian juga kepuasan kerja, sebagian besar dapat mempengaruhi kedisiplinan tetapi ada juga yang tidak berpengaruh terhadap kedisiplinan (Jaya, 2015). Perbedaan penelitian inilah yang menunjukkan perlunya penelitian kembali untuk menguji, membuktikan dan menambahkan temuan baru.

Budaya organisasi adalah hal yang sangat penting dalam organisasi dalam untuk menjadi pedoman pegawai dalam melaksanakan kewajibannya. Lembaga pendidikan tinggi secara umum telah memperbaiki pola budaya organisasi dengan finger print untuk absen datang 
dan pulang pegawai, peyampaian pengumuman melalui pesan whatshapp dan penyampaian laporan bulanan melalui sistem aplikasi. Namun demikian masih ada beberapa pegawai pelanggaran yang terjadi. Masih banyak pegawai yang tidak memahami budaya organisasi sehingga masih banyak budaya pegawai yang tidak senada dengan budaya organisasi.

Budaya organisasi merupakan ciri khas yang melekat pada suatu organisasi yang memiliki pedoman-pedoman dan sanksi untuk mengatur pegawainya dalam bekerja. Budaya organisasi dikatakan memberi pedoman kepada seorang pegawai apabila pegawai tersebut dapat mempersepsikan karakteristik budaya yang ada di dalam organisasi tersebut, mulai dari nilai yang dibutuhkan dalam bekerja, berinteraksi dengan kelompok, berinteraksi dengan sistem serta berinteraksi dengan atasannya. Namun apabila budaya organisasi tidak memiliki pedoman dan kejelasan sanksi bagi pelanggar aturan, dapat mengakibatkan pegawai bertindak semaunya sendiri, hal ini membuat pegawai tidak takut untuk melanggar aturan yang ada. Tindakan tersebut merupakan indikasi bahwa pegawai tidak memiliki sikap disiplin. Sebaliknya, apabila suatu organisasi memiliki budaya organisasi yang kuat dan baik, maka akan terbentuk kebiasaan baik pegawai sesuai dengan budaya tersebut.

Adapun pengaruh budaya organisasi terhadap disiplin juga terdapat pada penelitian di PT Angkasa Pura II (Persero) Kantor Cabang Utama (KCU) Bandara Internasional Soekarno-Hatta Unit Personel \& General Affairs (Damayanti dan Fakhri, 2014). Budaya organisasi memiliki pengaruh yang positif dan signifikan terhadap disiplin di Kantor Pusat PT. Kereta Api Indonesia (Perser), budaya organisasi berpengaruh secara positif dan signifikan terhadap disiplin kerja pegawai (Oktaviani dan Saragih, 2017). Ada hubungan yang signifikan antara budaya organisasi dengan kedisiplinan kerja di PT. Krakatau Steel (Persero) (Pribadi dan Herlena, 2016). Terdapat pengaruh positif dan signifikan terhadap disiplin kerja di Satuan Polisi Pamong Praja Gunungkidul (Marhendro, 2016). Kebiasaan yang baik yang sesuai dengan budaya organisasi melekat dalam diri pegawai secara positif, mempengaruhi sikap serta perilakunya dan menjadikan pegawai tersebut terbiasa bekerja sesuai aturan. Hal tersebut menunjukkan adanya pengaruh antara budaya organisasi dan tingkat kedisiplinan pegawai.

Kompetensi merupakan suatu faktor yang mempengaruhi disiplin kerja pegawai karena apabila pekerjaan yang dibebankan kepada seorang pegawai sesuai dengan kemampuan pegawai yang bersangkutan, maka dia akan bekerja dengan sungguh-sungguh dan berdisiplin baik untuk mengerjakannya. Tetapi apabila pekerjaan itu diluar kemampuannya, maka kesungguhan dan kedisiplinan pegawai rendah (Hasibuan, 2008).

Kurangnya kompetensi sumber daya manusia terjadi di bidang tertentu misalnya pegawai di bagian program dan pelaporan tidak ada yang mengikuti diklat penyusunan renstra, tidak ada pegawai di bagian unit laboratorium khusus yang pengikuti pelatihan dan lain-lain. Pengamatan peneliti di lapangan menunjukkan upaya dalam memenuhi kepusaan kerja pegawai di lembaga pendidikan tinggi antara lain yaitu memberikan imbalan atau ganjaran atas hasil kerja berupa gaji, tunjangan kerja dan penghasilan tambahan pada saat melakukan tugas selain tugas pokok, menyediakan fasilitas kantor yang 
memadai dan adanya promosi dan kenaikan jabatan. Lembaga pendidikan tinggi menyelenggarakan pendidikan bagi masyarakat dengan memanfaatkan dana yang beragam yaitu sumber dana pemerintah, peserta didik, dan pihak terkait lainnya. Tugas dan kewajiban lembaga pendidikan tinggi semakin besar seiring bertambahnya jumlah peserta didik. Dengan jumlah pegawai yang tetap, mengharuskan pegawai untuk mengerjakan tugas diluar tugas pokok yang tentu saja tidak sesuai dengan SOP (Standar Operasional Prosedur). Hal ini merupakan salah satu yang reaksi ketidakpuasan pegawai dalam bekerja.

Adapun pengaruh kompetensi terhadap disiplin juga terdapat pada penelitian di SD Negeri se-Gugus Gatot Subroto, Kecamatan Kutasari, Kabupaten Purbalingga terdapat hubungan positif antara kompetensi deengan disiplin kerja (Rahayu, 2014). Pada Kelas V SD Se-Gugus I Sidoarum Godean Sleman Tahun Ajaran 2015/2016 terdapat pengaruh positif dan signifikan antara kompetensi kepribadian guru terhadap disiplin siswa (Widyaningsih, 2016). Di Dinas Pertanian dan Perikanan Kabupaten Indragiri Hulu, terdapat pengaruh yang signifikan antara kompetensi terhadap disiplin pegawai (Astraina, 2018). Kompetensi untuk melaksanakan suatu pekerjaan yang dilandasi dengan keterampilan dan pengetahuan, dimana kemampuan sikap dan perbuatan positif membuat pegawai lebih disiplin dalam melaksanakan tugasnya.

Kepuasan kerja dapat mempengaruhi disiplin kerja pegawai kearah yang lebih baik, hal ini disebabkan karena pegawai telah mencapai kepuasan psikologis yang memunculkan sikap positif dari pegawai. "Disiplin yang baik mencerminkan besarnya tanggung jawab seseorang terhadap tugas-tugas yang diberikan kepadanya. Hal ini mendorong gairah kerja, semangat kerja, dan terwujudnya tujuan perusahaan, pegawai, serta masyarakat pada umumnya" (Rivai dan Sagala, 2010:824).

Adapun pengaruh kepuasan terhadap disiplin juga terdapat pada penelitian di Bank Tabungan Negara (Persero) Kantor Cabang Syari'ah Malang ada pengaruh signifikan secara simultan dari kepuasan kerja terhadap disiplin kerja (Hadi, 2012). Kepuasan kerja mempunyai pengaruh secara signifikan dan positif terhadap disiplin kerja (Ilahi, Mukjan, Prasetya, 2017) di PT. PLN (Persero) Distribusi Jawa Timur Area Malang. Kepuasan kerja mempunyai pengaruh terhadap disiplin kerja di Resort Dangau Kota Singkawang (Sudarwin, 2014). Terdapat variabel kepuasan kerja berpengaruh terhadap disiplin kerja di PT.X Sukabumi (Tiara, Prakoso, 2018). Kepuasan kerja yang dicapai pegawai akan mempengaruhi kesediaan dan kerelaan yang diperoleh pegawai akan berdampak pada tingginya disiplin kerja pegawai.

\section{METODE PENELITIAN}

$\begin{array}{rrr}\text { Penelitian dilakukan } & \text { dengan } \\ \text { menyebarkan } & \text { kuesioner } & \text { dalam }\end{array}$ mendapatkan data penelitian. Kuesioner disebarkan kepada 146 pegawai Lembaga Pendidikan Tinggi di Bekasi.

Penelitian menggunakan empat varibel utama yaitu tiga variabel bebas dan satu variabel terikat. Variabel terikat dalam penelitian ini adalah disiplin kerja. Variabel bebas pada penelitian ini adalah budaya organisasi, kompetensi kerja dan kepuasan kerja. Tujuannya untuk menganalisis pengaruh budaya organisasi, disiplin dan kepuasan terhadap kinerja pegawai. 
Tabel 2. Operasionalisasi Variabel

\begin{tabular}{|c|c|c|}
\hline No. & Variabel & Indikator \\
\hline 1 & $\begin{array}{l}\text { Budaya Organisasi adalah Dasar organisasi } \\
\text { yang memuat keyakinan, norma-norma, } \\
\text { dan nilai-nilai tersebut menjadi pegangan } \\
\text { semua sumber daya manusia dalam } \\
\text { organisasi dan melaksanakan kinerjanya } \\
\text { (Robbins, 2015) }\end{array}$ & $\begin{array}{ll}\text { 1. } & \text { Inovasi } \\
\text { 2. } & \text { Pengambilan risiko } \\
\text { 3. } & \text { Memperhatikan detail } \\
\text { 4. } & \text { Orientasi hasil } \\
\text { 5. } & \text { Orientasi individu } \\
\text { 6. } & \text { Orientasi tim } \\
\text { 7. } & \text { Agresifitas } \\
\text { 8. } & \text { Stabilitas }\end{array}$ \\
\hline 2 & $\begin{array}{l}\text { Kompetensi adalah seperangkat } \\
\text { pengetahuan, keterampilan, perilaku yang } \\
\text { harus dimiliki seseorang dalam } \\
\text { melaksanakan tugas keprofesionalnya } \\
\text { (Pramudyo, 2010) }\end{array}$ & $\begin{array}{l}\text { 1. Pengalaman Kerja } \\
\text { 2. Latar Belakang Pendidikan } \\
\text { 3. Keahlian } \\
\text { 4. Pengetahuan } \\
\text { 5. Keterampilan }\end{array}$ \\
\hline 3 & $\begin{array}{l}\text { Kepuasan kerja adalah kondisi emosional } \\
\text { pada seorang pegawai yang senang dan } \\
\text { mencintai pekerjaannya (Hasibuan, 2008) }\end{array}$ & $\begin{array}{l}\text { 1. Senang } \\
\text { 2. Cinta } \\
\text { 3. Moral Positif } \\
\text { 4. Suka } \\
\text { 5. Puas }\end{array}$ \\
\hline 4 & $\begin{array}{l}\text { Disiplin adalah kepatuhan untuk } \\
\text { menghormati dan melaksanakan suatu } \\
\text { system yang mengharuskan orang untuk } \\
\text { tunduk pada keputusan, perintah atau } \\
\text { peraturan yang berlaku (Rivai, 2013) }\end{array}$ & $\begin{array}{l}\text { 1. Kehadiran } \\
\text { 2. Kewaspadaan } \\
\text { 3. Ketaatan } \\
\text { 4. Kepatuhan } \\
\text { 5. Etika }\end{array}$ \\
\hline
\end{tabular}

Penelitian dilakukan dengan pendekatan kuantitatif yaitu model inferensial menggunakan analisis regresi linier ganda. Sebagaimana kriteria analisis regresi linier ganda maka analisis dilakukan melalui tahapan uji instrumen, uji persyaratan analisis, uji model dan uji hipotesis.

Uji instrumen melalui uji validitas reliabilitas. Uji validitas menggunakan nilai corected item correlation sedangkan uji reliabilitas menggunakan Cronbach Alpha.

Uji persyaratan analisis yang digunakan adalah uji asumsi klasik yang terdiri dari normalitas, multikolinieritas, autokorelasi dan heteroskedastisitas.
Normalitas dilakukan secara grafis (histogram), multikolinieritas menggunakan VIF, autokorelasi menggunakan nilai durbin watson, dan heteroskedastisitas secara grafis dengan scatter plot.

Uji model digunakan untuk memastikan kelayakan model. Kelayakan model dilihat dari nilai $\mathrm{R}$ Square sedangkan pengujiannya dengan uji F.

Uji hipotesis menggunakan nilai koefisien regresi untuk menentukan arah pengaruh sedangkan pengujian dilakukan dengan uji-t. Koefisien regresi diperoleh dari persamaan regresi linier ganda unstandardized:

$\mathrm{Y}=\mathrm{a}+\mathrm{b} 1 \mathrm{X} 1+\mathrm{b} 2 \mathrm{X} 2+\mathrm{B} 3 \mathrm{X} 3$ 


\section{HASIL PENELITIAN}

Penelitian dilakukan dengan menyebarkan kuesioner kepada 162 pegawai Lembaga Pendidikan Tinggi di Bekasi. Kuesioner yang tidak kembali sebanyak 41 kuesioner, yang tidak lengkap sebanyak 25 kuesioner dan yang layak digunakan untuk analisis ada 96 kuesioner.

Jenis kelamin responden relatif berimbang antara pria (51\%) dan wanita (49\%). Sebagian besar responden (50\%) berusia 31 - 40 tahun dan sisanya terbagi pada kelompok < 31 tahun $(8,3 \%), 41-50$ tahun $(14,6 \%)$ dan $>50$ tahun sebesar $27,1 \%$. Pendidikan responden terbanyak adalah S2 (63,5\%) diikuti oleh Diploma, dan Sarjana dengan jumlah berimbang. Berdasar masa kerjanya, sebagian besar sudah bekerja lebih dari 15 tahun yaitu sebanyak $40,6 \%$.

Penelitian menggunakan instrumen kuesioner sehngga dilakukan uji instrumen yaitu validitas dan reliabilitas. Variabel budaya organisasi terdiri dari 8 (delapan) item kuesioner yang seluruhnya valid dan reliabel. Variabel kompetensi terdiri dari 5 (lima) item kuesioner yang seluruhnya valid dan reliabel. Variabel kepuasan kerja terdiri dari 5 (lima) item kuesioner yang seluruhnya valid dan reliabel. Disiplin kerja terdiri dari 5 (lima) item kuesioner yang seluruhnya valid dan reliabel. Data uji reliabilitas dapat dilihat pada tabel 2.

Tabel 2. Uji Reliabilitas

\begin{tabular}{cccl}
\hline Var. & Item & $\begin{array}{c}\text { Cronbch } \\
\text { Alpha }\end{array}$ & Kesimpulan \\
\hline BO & 8 & 0,761 & Reliabel \\
KM & 5 & 0,732 & Reliabel \\
KK & 5 & 0,795 & Reliabel \\
DK & 5 & 0,855 & Reliabel \\
\hline
\end{tabular}

Sumber: Data diolah, 2019
Penelitian menghasilkan temuan kategori pada masing-masing variabel sebagaimana tabel 3 .

Tabel 3. Statistik Deskriptif

\begin{tabular}{ccccc}
\hline Var. & Min. & Max. & Mean & Kategori \\
\hline DK & 3,100 & 5,000 & 4,184 & Tinggi \\
BO & 3,000 & 4,857 & 4,175 & Baik \\
KM & 3,700 & 5,000 & 4,352 & $\begin{array}{c}\text { Sangat } \\
\text { Tinggi }\end{array}$ \\
KK & 2,917 & 4,833 & 4,079 & Tinggi \\
\hline
\end{tabular}

Sumber: Data diolah, 2019

Persyaratan analisis regresi linier ganda telah terpenuhi. Normalitas terpenuhi karena grafik histogram hasil pengujian membentuk kurva yang seimbang. Multikolinieritas terpenuhi dengan diperolehnya nilai VIF kurang dari 2 untuk setiap variabel independen. Autokorelasi terpenuhi dengan diperolehnya nilai Durbin Watson = 2,208. Heteroskedastisitas terpenuhi dengan diperolehnya scatter plot yang menyebar secara acak.

Kelayakan model terlihat dari nilai koefisien determinasi sebesar 0,654 dan adjusted $\mathrm{R}$ square sebesar 0,643 sebagaimana terlihat pada tabel 4 .

Tabel 4. Koefisien Determinasi

\begin{tabular}{ccc}
\hline Variabel & \multicolumn{2}{c}{ Dependen: Disiplin } \\
\cline { 2 - 3 } Independen & $\mathrm{R}^{2}$ & Adjusted R ${ }^{2}$ \\
\hline Budaya & & \\
Organisasi, & 0,654 & 0,643 \\
Kompetensi, & & \\
Kepuasan Kerja & & \\
Sumber: Data diolah, 2019 &
\end{tabular}

Uji kelayakan model mendapat kesimpulan yang layak dimana hasil 
pengujian mendapatkan nilai Sig. F sebesar 0,000 atau dibawah taraf uji penelitian sehingga Ho ditolak. Hasil analisis untuk mendapatkan uji-F dapat dilihat di tabel 5 .

Tabel 5. Uji F

\begin{tabular}{cccc}
\hline Variabel & \multicolumn{3}{c}{ Dependen: Disiplin } \\
\cline { 2 - 4 } Independen & $F_{\text {hitung }}$ & Sig. & $\begin{array}{c}\text { Kesimpul } \\
\text { an }\end{array}$ \\
\hline $\begin{array}{c}\text { Budaya } \\
\text { Organisasi, } \\
\text { Kompetensi, } \\
\text { Kepuasan Kerja }\end{array}$ & 56,812 & 0,000 & $\begin{array}{c}\mathrm{H}_{0} \\
\text { ditolak }\end{array}$ \\
\hline
\end{tabular}

Sumber: Data diolah, 2019

Pengujian hipotesis dilakukan berdasar koefisien regresi dan nilai probabilitas sebagaimana terangkum pada tabel 6.

\begin{tabular}{lccc}
\multicolumn{3}{c}{ Tabel 6. Koefisien } \\
\hline \multirow{2}{*}{$\begin{array}{c}\text { Variabel } \\
\text { Independen }\end{array}$} & $\begin{array}{c}\text { Dependen : } \\
\text { Disiplin }(\mathrm{Y})\end{array}$ & $\begin{array}{c}\text { Kesimp } \\
\text { ulan }\end{array}$ \\
\cline { 2 - 3 } & Koef. & Sig. & \\
\hline (Constant) $)$ & 0,080 & 0,828 & - \\
\hline $\begin{array}{l}\text { Budaya } \\
\text { Organisasi } \\
\left(\mathrm{X}_{1}\right)\end{array}$ & 0,132 & 0,135 & $\begin{array}{c}\mathrm{H}_{1} \\
\text { ditolak }\end{array}$ \\
\hline $\begin{array}{l}\text { Kompetensi } \\
\left(\mathrm{X}_{2}\right)\end{array}$ & 0,342 & 0,000 & $\begin{array}{c}\mathrm{H}_{2} \\
\text { diterima }\end{array}$ \\
\hline $\begin{array}{l}\text { Kepuasan } \\
\text { Kerja }\left(\mathrm{X}_{3}\right)\end{array}$ & 0,510 & 0,000 & $\begin{array}{c}\mathrm{H}_{3} \\
\text { diterima }\end{array}$ \\
\hline
\end{tabular}

Sumber: Data diolah, 2019

Tabel 5 memperlihatkan hasil analisis yang dapat dibuat model persamaan regresi linier ganda:

$Y=0,080+0,132 X 1+0,342 X 2+0,510 X 3 \ldots 2)$

Nilai koefisien budaya organisasi sebesar 0,132 memiliki nilai sig. 0,135 sehingga H1 ditolak karena tidak signifikan. Nilai koefisian kompetensi sebesar b2 $=0,342$ memiliki nilai Sig. 0,000 yang berarti signifikan sehingga $\mathrm{H} 2$ diterima. Nilai koefisien kepuasan kerja sebesar b3 $=0,510$ memiliki nilai Sig. 0,000 yang berarti signifikan sehingga $\mathrm{H} 3$ diterima.

\section{PEMBAHASAN}

Penelitian menghasilkan temuan bahwa disiplin kerja, budaya organisasi, dan kepuasan kerja sudah tinggi atau baik. Bahkan kompetensi kerja pegawai sudah sangat tinggi. Hal ini menandakan bahwa sesungguhnya secara umum bahwa apa yang terjadi di organisasi sudah berjalan dengan baik.

Analisis data telah melalui serangkaian proses sesuai kaidah dimana telah diawali dengan pengujian instrumen dimana seluruh item kuesioner pada masing-masing variabel telah valid. Demikian juga tiap variabel telah reliabel sehingga data bisa digunakan untuk keperluan analisis.

Persyaratan analisis regresi linier ganda seluruhnya terpenuhi sehingga dimana data telah berdistribusi normal, modelnya baik karena tidak memiliki masalah multikolinieritas, tidak terjadi kesalahan rambang, dan benar-benar bersifat linier. Hal ini menandakan bahwa analisis regresi linier ganda menghasilkan model persamaan regresi linier ganda yang memenuhi kaidah BLUE (Best Linier Unbiased Estimated) sehingga analisis bisa dilanjutkan ke tahap berikutnya.

Model persamaan regresi linier ganda yang terbentuk layak digunakan untuk menerangkan pengaruh variabel independen terhadap variabel dependen. Model persamaan regresi linier ganda hasil penelitian pada model tersebut budaya organisasi, disiplin kerja dan kepuasan kerja mampu menjelaskan 64,3\% variasi disiplin kerja pegawai. 
Penelitian menghasilkan temuan berpengaruh terhadap disiplin kerja. Kompetensi kerja dan kepuasan kerja masig-masing berpengaruh degan arah positif terhadap disiplin kerja dimana kepuasan kerja lebih kuat dalam mempengaruhi disiplin kerja dibanding kepuasan kerja.

\section{Pengaruh Budaya Organisasi Terhadap Disiplin Kerja}

Budaya organisasi yang telah tertanam dan dilaksanakan atau bahkan menjadi sebuah aturan dalam sebuah instansi, tidak serta-merta membuat peningkatan kedisiplinan para pegawai itu sendiri. Hasil penelitian ini menunjukkan bahwa budaya organisasi tidak berpengaruh terhadap disiplin kerja. Hasil penelitian ini berlawanan dengan penelitian sebelumya yang menghasilkan temuanadanya pengaruh budaya organisasi terhadap disiplin kerja (Oktaviani dan Saragih, 2017). Semakin meningkatnya penerapan budaya organisasi dalam sebuah instansi seharusnya akan memberikan efek kedisiplinan bagi para pegawainya (Pribadi dan Herlena, 2016). Namun penelitian ini sejalan dengan temuan peneliti lain dimana budaya organisasi tidak memiliki pengaruh terhadap disiplin yang dilakukan pada Wartawan Tribun di Pekanbaru (Jaya, 2015). Hal ini menarik mengingat pemahaman nilai-nilai yang dianut organisasi atau disebut sebagai budaya organisasi oleh pegawai sebagai anggota organisasi seharusnya dapat mendisiplinkan pegawai tersebut. Hasil temuan ini perlu ditelaah kembali untuk lebih memastikan dan mengkonfirmasi kembali kebenaran adanya perubahan budaya organisasi yang tidak berdampak pada disiplin kerja.

\section{Pengaruh Kompetensi Terhadap Disiplin Kerja}

Kompetensi para pegawai dalam melakukan pekerjaan telah maksimal diterapkan dan memiliki pengaruh terhadap peningkatan kedisiplinan dalam lingkungan pekerjaan. Nilai koefisien yang dihasilkan dapat memberikan besaran arah pengaruh yaitu positif sehinga jika terjadi peningkatan kompetensi pegawai akan diikuti dengan meningkatnya disiplin kerja para pegawai. Hasil penelitian ini sekaligus membuktikan pentingnya kompetensi para pegawai agar benar-benar tertanam pada masing-masing individu guna menunjang kedisiplinan dalam melakukan serta menyelesaikan pekerjaan dalam instansi tersebut. Hasil penelitian ini sejalan dengan penelitian yang pernah ada (Rahayu, 2014; Widyaningsih, 2016; Ivalaina Astraina, 2018) yang menemukan adanya pengaruh kompetensi terhadap disiplin kerja. Kompetensi yang memiliki dasar keterampilan dan pengetahuan para pegawai akan senantiasa memberikan efek pada disiplin pegawai itu sendiri. Semakin meningkat kompetensi pegawai terbukti mampu meningkatkan disiplin kerja para pegawai.

\section{Pengaruh Kepuasan Kerja Terhadap Disiplin Kerja}

Kepuasan kerja para pegawai sangat menentukan tingkat disiplin pegawai dalam melakukan pekerjaan. Nilai yang dihasilkan mampu memberikan besaran arah pengaruh yaitu positif yang berarti ketika terjadi peningkatan kepuasan kerja pegawai akan diikuti dengan meningkatnya disiplin kerja para pegawai. Hasil penelitian ini sejalan dengan penelitian yang pernah ada (Prasetya dkk, 2017) yang menemukan adanya pengaruh kepuasan kerja terhadap disiplin kerja para pegawai. Semakin tinggi kepuasan yang 
dirasakan oleh para pegawai dalam bekerja akan memungkinkan terjadinya peningkatan pada disiplin kerja para pegawai itu sendiri.

\section{KESIMPULAN}

Penelitian menghasilkan model pengaruh Budaya Organisasi, Kompetensi dan Kepuasan Kerja terhadap Disiplin Kerja. Kompetendi dan kepuasan kerja berpengaruh dengan arah positif terhadap disiplin kerja tetapi budaya organisasi tidak berpengaruh terhadap disiplin kerja.
Perlu ditelaah kembali mengapa budaya organisasi tidak mempengaruhi disiplin kerja. Penelitian lebih lanjut dengan lingkup yang lebih luas perlu dilakukan. Perlu dipertimbangkan juga kemungkinan ada faktor lain yang menjembatani pengaruh budaya organisasi terhadap disiplin kerja.

Penelitian ini hanya terwakili beberapa Lembaga Pendidikan di Bekasi sehingga perlu dilakukan penelitian kembali dengan lingkup yang lebih luas dengan keterwakilan institusi yang lebih baik lagi.

\section{PUSTAKA}

Hasibuan, M.S.P. 2008, Manajemen Sumber Daya Manusia, Jakarta: PT Haji Masagung.

Mardalis. 2009. Metode Penelitian Suau Pendekatan Proposal. Jakara: Bumi Aksara.

Robbins, S.P. 2015. Perilaku Organisasi, Jilid 1, Edisi Bahasa Indonesia, Edisi ke Sembilan Jakarta: Gramedia.

Damayanti, Dwitya dan Mahendra Fakhri. 2014. Pengaruh Budaya Organisasi Terhadap Disiplin Kerja Karyawan PT Angkasa Pura II (Persero) Kantor Cabang Utama Bandara Internasional Soekarno-Hatta Unit Personel \& General Affairs.

Hadi, M.A. 2012. Pengaruh Kepuasan Kerja Terhadap Disiplin Kerja Karyawan (Pada PT. Bank Tabungan Negara (Persero) Kantor Cabang Syariah Malang).

Jaya, Ujang. 2015. Pengaruh Budaya Organisasi Terhadap Disiplin dan Produktivitas Wartawan Tribun Pekanbaru. Jom FEKON Universitas Riau. Vol.2, No.1.

Octaviani, Widya Dwi dan Romat Saragih. 2017. Pengaruh Budaya Organisasi Terhadap Disiplin Kerja Karyawan Kantor Pusat PT. Kereta Api Indonesia. e-Proceeding of Management. Vol.4, No.1. pp: 687. ISSN: 2355-9357.

Prasetya, Arik. dkk. 2017. Pengaruh Kepuasan Kerja Terhadap Disiplin Kerja dan Komitmen Organisasiional. Jurnal Akuntansi Bisnis, Vo.44. No.1.

Pribadi, M. Luhung dan Benny Herlena. 2016. Peran Budaya Organisasi Terhadap Disiplin Kerja Karyawan PT Krakatau Steel. Jurnal Ilmiah Psikologi, Psympathic. Vol.3, No.2. Hal: 225-234.

Sudarwin. 2014. Pengaruh Kepuasan Kerja Terhadap Disiplin Kerja Pada Resort Dangau Kota Singkawang.

Rahayu, Septi. 2014. Pengaruh Kompetensi Profesional Guru Terhadap Disiplin Kerja Guru SDN di Gugus Gatot Subroto Kecamatan Kutasari Kabupaten Purbalingga.

Tiara, Vieta Restu dan Hendro Prakoso. 2018. Pengaruh Kepuasan Kerja terhadap Disiplin Kerja Karyawan Bagian Produksi Toys PT. X Sukabumi. Prosiding Psikologi. ISSN: 24606448.

Widyaningsih. 2016. Pengaruh Kompetensi Kepribadian Guru Terhadap Dispilin Siswa Kelas V SD Se-Gugus I Sidoarum Godean Sleman Tahun Ajaran 2015/2016. 
Astraina, Ivalaina. 2018. Pengaruh Kompetensi dan Budaya Organisasi Terhadap Disiplin Pegawai Pada Dinas Pertanian dan Perikanan Kabupaten Indragiri Hulu. Jurnal Manajemen dan Bisnis. Volume VII, No. 3, September 2018 (Halaman 1-93). p-ISSN 23024313. e-ISSN 2621-4199. 